\title{
Nisab Calculation of Paddy Zakat in Kuta Malaka Sub-District, Aceh Besar District (Viewed According to the Mazhab Shafi'i)
}

\author{
Aria Sandra', Muhammad Yasir', Maimun Abdurrahman Amin', Husni' \\ ${ }^{1}$ College of Islamic Sciences (STIS)Nahdlatul Ulama Aceh, Indonesia \\ arig_sibria@yahoo.com
}

\begin{abstract}
Zakat is one of the pillars of Islam. Every person who has assets when he reaches the threshold of Nisab is obliged to issue zakat. Among the assets that are obligatory for zakat to be issued are agricultural products, in this case paddy. Provisions of paddy zakat in the Shafi'i school, zakat must be issued after the paddy is harvested and calculates the Nisab before cutting all costs that have been used. Whereas the practice carried out by the community is the cost cutting that has been used during the process of planting paddy before the yield of the zakat is issued. Zakat is paid for from the rest of the penen and after it is combined with the results of other fields. This study aims to find out how the community practices of Kuta Malaka Subdistrict, Aceh Besar District, about the calculation of paddy zakat syrup and what they are guiding in carrying out the process of calculating zakat alms.The results showed that the community practices of Kuta Malaka Subdistrict in Aceh Besar District, namely cutting costs that had been used during the process of planting paddy before issuing zakat first, contradicted the provisions of zakat (paddy) in the Shafi'i school.
\end{abstract}

Keywords : Nisab Calculation of paddy; Kuta Malaka Sub-district; Mazhab Shafi'i view

\section{Introduction}

Islamic religion is built on five pillars, namely: saying two sentences of creed, praying, paying zakat, fasting in the month of Ramadan and performing the Hajj for those who are able to do so. A new person is said to have perfect Islam, if he has done the five pillars. If one of the five left behind, the Islam is not perfect. This is excluded from the Hajj, because Hajj is a worship that requires many conditions.

Zakat is worship that has a double dimension, transitional and horizontal, therefore zakat has many meanings in human life. Zakat is also an mäliyah worship that has socio-economic dimensions and functions or gifted distribution of Allah, and is a manifestation of social solidarity. With zakat, it can create a prosperous society, where the relationship between one person and another is harmonious, peaceful and harmonious.

In many ways, Islam commands the rich to pay attention to the poor, namely by giving assistance and supporting them. The Qur'an categorizes people who demean orphans not to feed poor people, as religious liars.

Every property owned, there are rights of others. And if the rights of others are not issued, it will pollute all the results of hard work for life. Zakat is a means of cleansing property and is a proof of obedience to Allah Almighty. Zakat can balance between hablu minAllahandhablu min al-nās. When a human being desires the pleasure of Allah Almighty, the bridge is balanced between the pieties of hablu minAllahandhablu min al-nās. If it's not one of them, then Allah is not happy, and this displeasure causes God to revoke the blessings of the treasure. Whereas the blessings and assets that blessed is those issued by zakat. ${ }^{1}$

Zakat is an obligation for Muslims who have been determined in the Qur'an, the sunnah of the Prophet Muhammad and the consensus of the scholars. There is no choice for a Muslim

\footnotetext{
${ }^{1}$ Habib Syarif Muhammad Al-Aydrus, Agar Hidup Selalu Berkah, (Bandung: Mizan, 2009), P. 191.
} 
to leave zakat, if there are conditions in his property, because zakat is the right of the poor in the form of clothing, food and other necessities of life that are needed by everyone in their daily lives. $^{2}$

Sharia Islam has obliged zakat on assets, and among them are agricultural products (grains and fruits), which are issued during harvest or after harvest. According to some scholars, agricultural products that are obliged to be zakat are not only staple crops, but also produce vegetables such as chili, potatoes, cabbage, fruits and so on.

Whereas in the Shafi'i school, not all agricultural products must be issued zakat, but agricultural zakat is only limited to two types, namely: grains and fruits. The grains which are obliged to be zakat are in the form of staple foods in normal conditions, such as wheat, sya'itr, corn, peanuts, fül seeds, daqsah and paddy.

The obligation to issue zakat from agricultural products is based on the word of Allah, in Surat Al-Baqarah verse 276:

"O you who have believed, spend from the good things which you have earned and from that which We have produced for you from the earth. And do not aim toward the defective therefrom, spending [from that] while you would not take it [yourself] except with closed eyes. And know that Allah is Free of need and Praiseworthy."

Saw:

Besides the obligation of zakat is also based on the hadith of the Prophet Muhammad

$$
\begin{aligned}
& \text { عن محمد بن عبيد الله عن عمرو بن شعيب عن ابيه عن جده قال انما سن رسول الله صلى الله عليه } \\
& \text { وسلام الزكاة في هذه الخمسة في الحنطة والشعير والتمر والزبيب والأرزة. (روواه ابن ماجه). }
\end{aligned}
$$

Meaning: From Muhammad bin Ubaidillah from Umar bin Syu ib from his fatherfrom his grandfather has been said:"Verily the Messenger of Allah has obliged on five types of grains, namely, hinthah (fine wheat), Sya ìr (coarse wheat) dates, zabīb and paddy. (H.R Ibnu Mājah)

If someone's assets have reached Nisab, then the assets are obliged to be issued zakat. As for the seeds of paddy (paddy) which must be issued zakat is 5 times, or approximately approximately $663 \mathrm{~kg}$ of the harvest. If the yield reaches a level of $663 \mathrm{~kg}$ as a threshold for Nisab, then the zakat must be paid $10 \%$, if the liquid is poured with rainwater or river flow, it does not require a fee. And if the paddy plants are watered using costs, then the zakat issued is $5 \%$.

Such provisions are based on the hadith of the Prophet Muhammad, namely:

$$
\text { عشن سا لم بن عبد الله عن ابيه رضي الله عنه عن النبي صلى الله عليه وسلام قال فيما سقت السماء والعيون كان }
$$

Meaning: From Sālim bin Abdullah r.afrom his fatherfrom Rasulullah Sawsaid that theplants that are only watered with rain, ground water, zakat is one tenth, and watered with water is drained, the zakat is one fifth. (H.R Al-Bukhāri)

\footnotetext{
${ }^{2}$ Mubyarto, Pengantar Ekonomi Pertanian dan Ekonomi Islam, (Jakrta: Pustaka LP3JS Indonesia, 1995), P. 12.
} 


\section{Review of Literature}

\subsection{Nisab Calculation of Zakat}

\section{a. Zakat on Leased Paddy Fields}

In the implementation of paddy zakat payments in Kuta Malaka Subdistrict, Aceh Besar Regency, there are differences between the practice of the community and fiqh theory in the Shafi'i School and with some other schools such as the Maliki School. This difference occurs in the process of calculating the Nisab.

People in Kuta Malaka Subdistrict, Aceh Besar Regency are actually aware of the obligation to issue zakat. But it is caused by practices that are different from the provisions of the implementation of zakat regulated in fiqh, in this case the Shafi'i school fiqh which results in some people not issuing zakat.

The calculation of Nisab carried out by the people of Kuta Malaka Subdistrict, Greater Aceh Regency so far is by first issuing all costs that have been incurred during the planting process, starting from the cost of renting land, fertilizer costs, seedling costs up to the cost of grinding. ${ }^{3}$

Cutting costs is done in a way, dividing the crop into three or two parts, depending on the paddy fields that are cultivated. If the paddy fields that are cultivated belong to someone else, then the yield is divided into three, namely, one portion as a paddy field rental and 2 parts for the person working on the field. ${ }^{4}$

Distribution of yields to these three parts is out of the cost of fertilizers and seeds. The costs of fertilizers and seeds are issued separately from the three divisions mentioned. ${ }^{5}$

For example, if a piece of paddy with a size of one yÔk, in terms of the community of Kuta Malaka Subdistrict or measuring 2000-2500 m, or menghasilkan h, produces 30 sacks of paddy or more, then the first thing to do is that the worker first removes 2 or three sacks depending on how many seeds were brought, so that the paddy from the amount of 30 sacks has become 27 or 28 sacks, then the cost of fertilizer is taken 2 or 3 sacks so that the remaining paddy becomes 23 or 24 sacks, then the remaining 24 sacks are distributed to 3 bahagian, 8 sacks to rent land and 16 sacks for the person who works the land, while the seeds and fertilizers are returned to who owns, if the owner is the farmer then returned to the farmer and if the owner is the owner then returned to the farmer land owner. ${ }^{6}$

As calculated as Nisab Zakat is the result of 16 sacks that are the result of their work, while the portion that has been issued earlier, such as the portion of seeds, fertilizers and land rent is not included in the Nisab calculation because it is considered as capital and out of the zakat property. Practices like this never seem to reach Nisab if we look at the habits of crops, and in the end from these practices have an impact on not paying zakat. ${ }^{7}$

Cutting costs and renting paddy fields is done directly in the paddy fields. After the paddy is cleared from grain and straw, paddy is not brought home first to the house before they spend all the costs mentioned above. ${ }^{8}$

\footnotetext{
${ }^{3}$ The results of the interview with Ibu Rahati, which is the Tumbo Baro Society, Duson Bineh Blang on December 4, 2016.

${ }^{4}$ The results of the interview with Mrs. Zairina, who is a resident of the village of Tumbo Baro, dusun Pusat,

${ }^{5}$ The results of the interview with Ibuk Nurmala who are residents of Lam Siteh Village, on December 15, 2016.

${ }^{6}$ The results of the interview with Mr. Abd. Munir, a resident of Lambaro Samahani Village, on April 10, 2017.

7 The results of the interview with Mr. Abd. Munir.

${ }^{8}$ Interview with Mr. Abd. Munir.
} 
As for zakat, each of them will be given between workers and landowners. To see the arrival of the Nisab boundary, they will collect with other paddy fields if the owner of the paddy field has several other fields, and the worker if there are other fields that he is working on. ${ }^{9}$

\section{b. Zakat on Private Rice Fields}

In the process of paying zakat in the District of Kuta Malaka, the District of Aceh Besar varies from one another. This difference is due to the different status of the paddy fields being worked on, some of them are rice fields on other people's land with rental status and some are rice fields on their own land.

If someone works on someone else's rice field, then the yield is divided into three after first releasing new seeds and fertilizers then the zakat is seen as explained in the previous discussion.

As for people who paddy on their own land, then the harvest is automatically fully owned by people who have these fields because they do not need to share with others.

Regarding the payment of zakat on this private rice field, it depends on the personalities of each person, some of the people who issue zakat if they arrive at Nisab by not taking the costs previously incurred such as seeds and fertilizers and other costs. ${ }^{10}$

And there are also those who take in advance any costs that have been incurred such as the cost of fertilizers, seeds and plow wages, and then the zakat will be calculated until or not Nisab, if until then zakat is issued and not arrived, zakat will not be issued even though the overall results have reached threshold of Nisab. ${ }^{11}$

For people who cut costs, they assume that the costs that have been incurred are their capital, so that capital must be spent first and then see the benefits they can be given zakat rights. In this case, depending on the results of the fields they get, if the results still reach Nisab they will pay Zakat.

As for the yields generally are very varied, there are those who get more than six gunca yields in one yoke and those with less than 6 gongs, but in general, if the paddy fields exchange 1 yoke or $1 / 4$ hectare then the results obtained are not less than 6 gunca. ${ }^{12}$

\subsection{How to Determine Nisab Zakat}

The calculation of the applicable Nisab limits in Kuta Malaka Subdistrict is varied, there are those who count the number of gunca, which is as many as 6 guncas, for regions that impose a number of shakes, such as Tumbo Baro Village, Gampong Lambaro Samahani, Gampong Lam Ara Cut. and there are also those who set the threshold of Nisab with cans, that is as many as 100 cans, for villages that apply the calculation of Nisab to the number of cans, such as Gampong Lamsiteh Cot, and Gampong Lam Ara Eungkit. ${ }^{13}$

The details of the gunca are as follows: 6 rice guncas, equal to 60 gods, in one way, equal to $20 \mathrm{~kg}$, if multiplied, $20 \mathrm{~kg} \mathrm{x} 60$ trees is equal to $1200 \mathrm{~kg}$, then the threshold of rice Nisab with a scale is $1200 \mathrm{~kg}$. while in one sack, there are 2 gods, if multiplied by 30 sacks, then there are 60 gods, then thirty sacks are 6 guncas.

\footnotetext{
9 Interview with Mr. Abd. Munir.

${ }^{10}$ The interview with Mr Munadi Yusuf, a resident of Lam Ara Cut Village, on April 10, 2017.

${ }^{11}$ Interview with Mr. Munadi Yusuf.

${ }^{12}$ Hasil wawancara dengan Bapak Mustajib sebagai warga Lam Ara Cut, pada tanggal 10 April 2017.

${ }^{13}$ Interview with Mr. Khalid Wardana, Geusyik Tumbo Baro Village. On December 7, 2016.
} 
Whereas those using cans, the details are, in one can, weighing $12 \mathrm{~kg}$, and $12 \mathrm{~kg}$ multiplied by 100 cans, the amount is $1200 \mathrm{~kg}$. then the dose of 100 cans and 6 gunca is the same.

If the yield of the rice field gets 30 sacks ( 6 gunca) or 100 cans, then it is compulsory for zakat, however, due to cutting costs first so that the rice with 30 sacks or 100 cans that have been obtained will no longer reach the threshold of Nisab.

Apart from that, the author also found another answer from the community, that they had just issued zakat if they got 30 sacks, while to get 30 sacks, the yield had to be combined with the other rice fields, that is, a farmer hijacked 3 rice fields if the yield in one plot of rice is 10 sacks after cutting costs, then combined with the number of rice fields cultivated, if it reaches the threshold of Nisab, then the zakat will only be issued. ${ }^{14}$

In fact, if it refers to the fiqh theory, Nisab is calculated from the overall results and there should be no deduction of costs before the zakat is issued, other than deductions that are justified by syara 'that is related to the way of irrigating water into the fields.

Then, if a farmer works on three fields, each of them gets the results up to the threshold of 30 sacks or 100 cans, then the zakat must be issued for three fields, if in one case the paddy gets 3 sacks as zakat rights, then of the three paddy fields get 9 sacks for zakat, and if the paddy produced by each paddled rice field does not reach the threshold of the Nisab, the cultivator is required to combine all the yields of the paddy fields obtained from all cultivated fields to count up or not the amount the Nisab.

But in reality what happens in the community is not the case, but as what has been explained in the previous discussion, so that many people do not pay zakat because they think that their harvest does not reach the threshold of Nisab.

\subsection{Community Guidelines / Handles in Paying Zakat}

Allah Almighty has revealed the Qur'an as a guide to human life, especially those who believe in Him, and has sent the Apostles to deliver His Shari'at and the ulama were born to explain the issues related to the Shara law.

Humans are obliged to cling to the Qur'an and the sunnah of the Prophet in carrying out all the orders that have been obliged by Allah, so as not to do wrong.

The issue of zakat is one of the problems that has been regulated in the Qur'an and the sunnah of the Prophet Muhammad, although in language that is still common, however, Muslims must refer to the Qur'an and the hadith of the Prophet Muhammad.

Related to the implementation of zakat from agricultural products in the District of Kuta Malaka, Aceh Besar Regency, the authors found that farmers were not as devoted as referring to the provisions of fiqh which are the essence of the Qur'an and hadith of the Prophet Muhammad, because after being traced the main guideline of the Kuta Malaka District so far in paying zakat is based on customs or habits that they have been doing for years and from generation to generation. ${ }^{15}$

The community followed the practices of the people before them, while the practice was unknown, even they never questioned them. Of all the informants interviewed, none of them knew the origin of this practice.

In the public perception, the practices they have carried out so far have been correct and in accordance with Islamic teachings and in accordance with the concept of fiqh, not even a

\footnotetext{
${ }^{14}$ Results of interview with Ms. Siti Badriah, Lam village Ara Eungkiet, December 6, 2016.

15 The results of the interview with Ibuk Zubaidah residents of Lam Ara Eungkit on December 27, 2016.
} 
few of the people consider the process of calculating zisab wrongly arranged according to the Shafi'i fiqh, moreover for those who in their daily speech do not follow the school.

From the results of the research that the authors did, there were no other answers from the community related to their reference to the issue of zakat payment procedures, apart from the answers to the practices of previous people, in this case it was an indication that this community practice was not based on a single school of school - schools that are mu'tabar.

It seems that the practice of their parents in the past will continue to be used as a reference or reference in issuing zakat, even more so if not given the correct understanding that is in accordance with fiqh theory, in addition to the low level of public awareness in following majelista recitations. lim.

Associated with this community practice, in the author's opinion, there is a disconnected link between the practice of previous people and the present society, the author's observation is based on a report by some people who say that their parents were also active in recitations, with read books in the Shafi'i school, such as the book Matla 'Al-Badraini by Syekh Muhammad bin Isma'il Daud Fațāni, and the book Sabila Al-Muhtadin by Sheikh Nuruddin Ar-Raniry and other books. ${ }^{16}$

\subsection{Community Guidelines / Handles in Paying Zakat}

Allah Almighty has revealed the Qur'an as a guide to human life, especially those who believe in Him, and has sent the Apostles to deliver His Shari'at and the ulama were born to explain the issues related to the Shara law.

Humans are obliged to cling to the Qur'an and the sunnah of the Prophet in carrying out all the orders that have been obliged by Allah, so as not to do wrong.

The issue of zakat is one of the problems that has been regulated in the Qur'an and the sunnah of the Prophet Muhammad, although in language that is still common, however, Muslims must refer to the Qur'an and the hadith of the Prophet Muhammad.

Related to the implementation of zakat from agricultural products in the District of Kuta Malaka, Aceh Besar Regency, the authors found that farmers were not as devoted as referring to the provisions of fiqh which are the essence of the Qur'an and hadith of the Prophet Muhammad, because after being traced the main guideline of the Kuta Malaka District so far in paying zakat is based on customs or habits that they have been doing for years and from generation to generation. ${ }^{17}$

The community followed the practices of the people before them, while the practice was unknown, even they never questioned them. Of all the informants interviewed, none of them knew the origin of this practice.

In the public perception, the practices they have carried out so far have been correct and in accordance with Islamic teachings and in accordance with the concept of fiqh, not even a few of the people consider the process of calculating zisab wrongly arranged according to the Shafi'i fiqh, moreover for those who in their daily speech do not follow the school.

From the results of the research that the authors did, there were no other answers from the community related to their reference to the issue of zakat payment procedures, apart from the answers to the practices of previous people, in this case it was an indication that this community practice was not based on a single school of school - schools that are mu'tabar.

\footnotetext{
${ }^{16}$ Interview with Ibuk Umamah, 84 years old, one of the residents of Tumbo Baro, on November 14, 2016.

17 The results of the interview with Ibuk Zubaidah residents of Lam Ara Eungkit on December 27, 2016.
} 
It seems that the practice of their parents in the past will continue to be used as a reference or reference in issuing zakat, even more so if not given the correct understanding that is in accordance with fiqh theory, in addition to the low level of public awareness in following majelista recitations. lim.

Associated with this community practice, in the author's opinion, there is a disconnected link between the practice of previous people and the present society, the author's observation is based on a report by some people who say that their parents were also active in recitations, with read books in the Shafi'i school, such as the book Matla 'Al-Badraini by Syekh Muhammad bin Isma'il Daud Fațāni, and the book Sabila Al-Muhtadin by Sheikh Nuruddin Ar-Raniry and other books. ${ }^{18}$

\section{Research Methods}

This research is a case study field study, with a qualitative approach. Qualitative use is considered more appropriate because the focus of this research is more about processes and requires deep observation with natural settings. In addition, the use of this approach is due to a research process and understanding based on methodologies that investigate social phenomena and human problems from the terms of reference of the research subjects themselves, namely how subjects perceive and interpret activities in terms of their establishment called "emic perception". ${ }^{19}$

The qualitative approach itself is often called the naturalistic approach, namely an approach that seeks to examine the focus of research by way of participating naturally so as to obtain comprehensive and in-depth results.

This research is a more directed research to look for field data, namely respondents, who come from villages in Kuta Malaka District, Aceh Besar District.

Given that Kuta Malaka District has a large area and consists of 15 villages, this study was only carried out in 5 villages as a sample, which was representative of other villages namely:

a. Tumbo Baro Village

b. Lambaro Samahani Village.

c. Lam Ara Eungkit Village

d. Lamsiteh Cot Village

e. Lam Ara Cut Village

\section{Discussions}

\subsection{Overview of the Shafi'i School against the Calculation of Rice Zakat Nisab in Kuta Malaka District.}

The calculation of seed grains, such as wheat seeds, rice and others, is carried out to coincide with the time of zakat collection, ie after the seeds are dried and cleaned from the skin, unless they are to be stored with stalks and skin and eaten as they like, such as corn which is crushed along with the skin according to its habits. So the skin is taken into account, because the skin is food even though it is sometimes cleaned to make it delicious as it is cleaned of wheat skin. Likewise fruits are dates and grapes. ${ }^{20}$

\footnotetext{
${ }^{18}$ Interview with Ibuk Umamah, 84 years old, one of the residents of Tumbo Baro, on November 14, 2016.

${ }^{19}$ Nasution Metode Penelitian Naturalistik kualitatif, (Bandung: Transito, 1996), P. 26.

${ }^{20}$ Muhammad Bin Idris Al-Syafì i, Al-Uum, (Bairut: Dār Al-Fikr, 2002), PRINT. I. P. 39.
} 
As stated in the Qur'an, Al-An'am.Meaning: "and give up the rights on the day to reap the results"

Related to this verse, Imam Sayafi'i gives an explanation, namely Allah Almighty does not set another time to take zakat apart from the time to take the results. And the word of God Almighty is understood, with the intention after being cleansed and dried, as explained by the hadith of the Prophet Muhammad. ${ }^{21}$

The explanation above, gives an understanding that, zakat is taken from the overall harvest, as well as the calculation of Nisab, carried out on the overall harvest.

Whereas in the harvesting process, cleaning of the grain and drying, is needed for costs, while the costs associated with the mentioned case are not taken from the assets of the zakat, so the harvest may not be divided before the Nisab is calculated and before the zakat is paid. This is explained by Imam Al-Nawawi in the book Al-Majmu 'Syarah Al-Muhazzab, as he said

$$
\text { ولمؤنة بتفيف التمر وجذاذه وحصاد الحب وممله ودياسه وتصفيته وحفضه وغير ذلك من مؤنة تكون }
$$

Artinya: As for the cost of drying grapes and cutting grain, transportation, drying, cleaning, maintenance and so on, all these costs are purely from the property of the owner of fruits and grains which are not given anything from the assets of zakat with no mistake. If the owner of fruit and grain issues all the costs mentioned from the assets of the zakat, then he must replace them with his property, and this problem there is no difference of opinion among us (the Shafi'i school). The author of the book Al-Hawi recounts that originating from 'Atha, ibn Abi Rabah he said "in fact the cost was taken from a mixture of assets, which were not reserved for the owner of fruits and grains solely in the absence of the indigent, because the property was shared, then the fee is taken from the wealth of zakat "the author of the Al-Häwi says" these words are wrong ".

A similar explanation is also given by, Sayid Muhammad Syața Al-Dimyati in the book I’ānah Al-Ṭālibīn he said

$$
\begin{aligned}
& \text { ان مؤنة الحصاد والدياسة ومثلهما مؤنة جذاذ الثمر وبتحيفه تكون من خالص مال المالك للزرع سواء كان مالكا } \\
& \text { للأرض ايضا ام لا بأن كان مستأجرا لها لا من مال الزكاة وكثيرا ما يخرجون ذلك من التمر او الحب ثنم يزكون } \\
& \text { الباقي وهو خطاء ويدل لما زكرته عبارة الروض وشرحه ونصها فرع. مؤنة الجفاف والتصفية والجذاذ والدياساة } \\
& \text { والحمل وغير } \\
& \text { ذلك مما يحتاج الى مؤنة على المالك لا من مال الزكاة.23. }
\end{aligned}
$$

${ }^{21}$ Muhammad Bin Idris Al-Syafi i, Al-Uum,,, PRINT. I. P.39

${ }^{22}$ Al-Nawawi, Majmu` Syarah Al-Muhazzab,,,Print. V. hlm.428.

${ }^{23}$ Sayid Muhammad Syața Al-Dimiyați, I ānah Al-Ṭālibīn, (Semarang: Taha Putra, tt), Print. II. P. 164. 
Meaning: Indeed, the cost of deduction and cleaning and similar to both are taken from the owner's property, whether the land being cultivated is owned by itself or as rented land, not taken from the assets of zakat, whereas what is mostly done is issuing all costs it has been spent, then from the rest the new is given to zakat, then that is wrong. and as a supporter of what I have said is AlNawawi's words in the book Raudhah wa Syarah written on a furu' "that all costs related to drying, cleaning, destroying and transporting and everything that needs costs is taken from the property of the grain owner is not from the assets of zakat.

The same information also delivered by Wahbah Al-Zuhaili in the book Fiqh Al-Islami wa Adillatuh, he said:

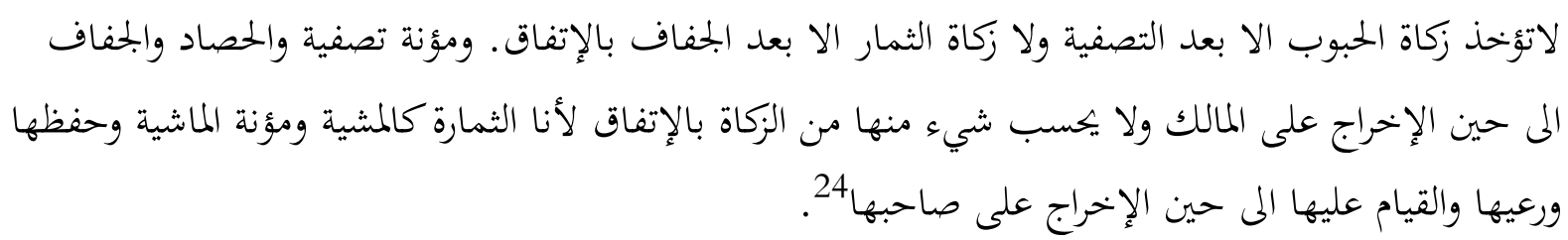

Meaning: It is not permissible to take zakat from the grain except after it is clean and no fruit zakat is taken except after it is dried by agreement of the ulama. The cost of cleaning, harvesting, drying up to the time the zakat is issued is above the owner of the grain and fruits, and nothing is calculated from the cost of the zakat by agreeing with the ulama, because fruits are the same as animals while maintenance costs animals, grazing animals and taking care of them until the time the zakat is issued is above the owner.

In addition, the same explanation is also found in the book Al-Bayān, namely:

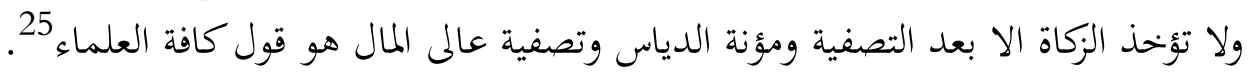

Meaning: Tidak diambilkan zakat kecuali setelah dibersihkan, adapun biaya pembersihan adalah di atas si pemilik harta, yang demikian itu adalah pendapat mayoritas ulama.

In the matter of this financing there are indeed differences of opinion among the fiqh scholars. Ibn Umar and Imam Abu Hanifah argued that if someone borrowed money to finance agriculture and the cost of living for his family, then all these costs must be spent first on agricultural products. If the remaining agricultural produce is still enough for one Nisab, 5\% of the zakat must be issued if the farm is irrigated with human labor, and $10 \%$ if it is irrigated with rainwater. According to Ibnu Abbas, the debt taken from agricultural products is only used for agricultural costs, not including the living costs of farmers and their families. After all the agricultural costs are incurred then the zakat is paid. ${ }^{26}$

Imam Ahmad bin Hambal expressed two opinions, namely someone who borrows money for the cost of agriculture and his family, then what is released from agricultural products is

\footnotetext{
${ }^{24}$ Wahbah Al-Zuhaili, Al-Fiqhu Al-Islami wa Adillatuhu,,, Print. I. P. $743 .$.

${ }^{25}$ Al-Husaini Yahya bin Abi Al-Khaira Salimi Al-`Imrani, Al-Bayān fī Mazhab Al-Imāmi Al-Syafì i, (Bairut: Daar Al-Manhaj, tt), Print. III, P. 261.

${ }^{26}$ Ensiklopedi Hukum Islam,,,P.1995.
} 
only the cost of agriculture. While the costs for families during farming are not taken into account. His second opinion said that all the costs needed during farming (agricultural costs and family expenses) were issued first from agricultural products, and if there was still one Nisab left, then the zakat was issued. ${ }^{27}$

\section{Conclusion}

The practice that applies to the people of Kuta Malaka Subdistrict, Aceh Besar Regency, in issuing rice zakat is by cutting off all the costs that have been used during the rice planting process, such as seed costs, fertilizers and land rent, and the rest is calculated by Nisab. Associated with the practice of this community, contradicting the provisions of zakat in the Shafi'i school, as a school of majority Muslims in Indonesia and in Aceh in particular.

When rice reaches the threshold of the Nisab, it is obligatory for the owner to issue zakat, with the provision that if the water is sourced from irrigation, rivers and the like then the level of zakat that must be issued is $10 \%$ and if the water is entered by means of a machine the amount of zakat that must be issued is $5 \%$.

In the process of payment of rice zakat in Kuta Malaka Sub-district, the community is still guided by the practices of previous people. They do not make one of the mu'tabar schools in fiqh a reference in the process of paying zakat. In people's perceptions, what they have done so far in relation to cutting costs that have been used during the rice cultivation process is correct and in accordance with Islamic law.

\section{References}

Al-Husaini Yahya bin Abi Al-Khaira Salimi Al-`Imrani, Al-Bayān fī Mazhab Al-Imāmi AlSyafi i, Bairut: Daar Al-Manhaj.

Bagong Suyanto, Metode Penelitian Sosial, Berbagai Alternatif pendekatan, Jakarta: Kencana, 2007.

Bambang Prasetio, Metode Penelitian Kualitatif dan Aplikasi, Jakarta: Raja Grafindo Persada, 2007.

Buku Kecamatan Kuta Malaka Dalam Angka 2015, published by Badan Pusat Statistik (BPS) Kabupaten Aceh Besar.

Deddy Mulyana, Metodologi Penelitian kualitatif Paradigma Baru Ilmu Komunikasi dan Ilmu sosial Lainnya, Bandung: Remaja Rosda Karya, 2001.

Habib Syarif Muhammad Al-Aydrus, Agar Hidup Selalu Berkah, Bandung: Mizan, 2009.

http://zakat. or. id/ cara menentukan zakat hasil pertanian, accessed on November 14, 2012.

KN, Sofyan Pengantar Hukum Zakat dan Wakaf, Surabaya: Al-Iklas, 1995.

Mubyarto, Pengantar Ekonomi Pertanian dan Ekonomi Islam, Jakrta: Pustaka LP3JS Indonesia, 1995.

Muhammad bin Yazid Al-Khazwaini, Sunan Ibnu Mājah, Lebanon: Dār Al-Fikr, 2004.

Muhammad Al-Husaini bin Mas`ūd bin Muhammad Al-Fara`i, Al-Tahzīb Fi Fiqh Al-Imam Al-Syafi i, Bairut: Dār Al-Kutub Al-Ilmiyah.

Muhammad Bin Idris Al-Syafi` i, Al-Uum, Bairut: Dār Al-Fikr, 2002.

Muhammad Ibnu Isma`̄il Al-Bukhār, Shahīh Al-Bukhāri, Bairut: Dār Al-Fikr, 1994.

${ }^{27}$ Ensiklopedi Hukum Islam,,,P.1995. 
www.bircu-journal.com/index.php/birci emails: birci.journal@gmail.com birci.journal.org@gmail.com

Muslim Ibrahim, Kajian Tinggi Ke-Islaman, Aceh Darusalam: Biro Keistimewaan dan Kesejahtraan Rakyat, 2008.

Nasution Metode Penelitian Naturalistik kualitatif, Bandung: Transito, 1996.

Said Muhammad Syața, I’ānah Al- Thālibīn, Semarang: Taha Putra

Sayid Muhammad Syaṭa Al-Dimiyați, I’ānah Al-Ṭālibīn, Semarang: Taha Putra 